\title{
EKSPRESI Tumor Necrosis Factor alpha (TNF-a) DAN Transforming growth factors beta (TGF-ß) PADA PERIODONTITIS APIKALIS KRONIS AKIBAT INDUKSI Enterococcus faecalis PADA TIKUS WISTAR
}

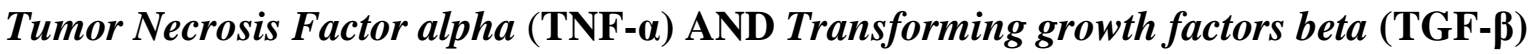 EXPRESSION IN PERIAPICAL TISSUE DAMAGE DUE TO Enterococcus faecalis INDUCTION AT WISTAR RAT}

\author{
Richard Fritzgerald*, Cecilia Lunardhi**,Ruslan Effendy**,Tamara Yuanita** \\ * Mahasiswa Spesialis Departemen Konservasi Gigi Fakultas Kedokteran Gigi Universitas \\ Airlangga,Surabaya,Indonesia \\ ** Departemen Konservasi Gigi Fakultas Kedokteran Gigi Universitas Airlangga,Surabaya,Indonesia
}

\begin{abstract}
Background. Root canal treatment is a main role in decreasing infection from root canal and pulp. The main cause of periapical damage mostly are bacteries. E.faecalis is a bactery that is found as an etiology of endodontic treatment failure. Cell wall of this bacteria is containing Lipoteichoic acid (LTA). LTA can penetrate into the periradicular tissue, act as endotoxin in host and cause periradicular inflammation then lead to bone destruction. LTA stimulates immunology reaction that produce Tumor Necrosis Factor alpha (TNF- $\alpha)$ and Transforming growth factors beta (TGF- $\beta)$. TNF- $\alpha$ is a main mediator and also have an important role in inflamation response otherwise $T G F-\beta$ is working as a multifunction regulator of cell growth and differentiation during reforming and remodelling. Purpose. The aim of this study is to know about the expression of TNF- $\alpha$ and TGF- $\beta$ during the periapical tissue damage due to induction of E.faecalis. Method. This study used laboratory experimental with the post test only control group design. A total of 30 male rats were randomly divided into 3 main groups, Group A (control negative) : normal tooth. Group B (control positive) : every tooth was induced only by sterile BHI-b. Group $C$ (treated group) : every tooth was induced by $10 \mu \mathrm{l}$ BHI-b E.faecalis ATCC212(10 $\mathrm{CFU})$. The animals were sacrificed 21 days later and prepared for histological examination of tissue damage, then we did the immunohistochemistry followed by calculation on the light microscope. Result. The analysis revealed that the expression of TNF- $\alpha$ at treated group are higher than negative control and positive control but the expression of TGF- $\beta$ at treated group are higher than the negative control group but lower than positive control. Conclusion. From this study we know that the expression of TNF- $\alpha$ and $T G F-\beta$ are changing during the periapical tissue damage that induced by E.faecalis.
\end{abstract}

Keywords : TNF- $\alpha, T G F-\beta$, E.faecalis, tissue damage

\section{PENDAHULUAN}

Karies gigi merupakan penyakit dengan kasus yang paling banyak, menempati urutan pertama dari beberapa daftar penyakit di Indonesia. Data Kementerian Kesehatan 2010 menunjukkan, bahwa prevalensi karies di Indonesia mencapai 60-80 \% dari populasi. Hasil Riset Kesehatan Dasar (Riskesdas)
Nasional tahun 2013 melaporkan prevalensi jumlah gigi yang tidak dirawat mencapai $68,9 \%$. Prevelansi karies di Indonesia mencapai $90,05 \%$ dan ini tergolong lebih tinggi dibandingkan dengan negara berkembang lainnya.

E.faecaelis merupakan bakteri yang paling sering ditemukan dan sebagai penyebab $85-90 \%$ infeksi Enterococcus. E.faecalis merupakan bakteri yang paling sering ditemukan dan sebagai penyebab 85-90\% infeksi Enterococcus). ${ }^{1}$ Penelitian Kowalski et al (2006) menunjukkan bahwa 
prevalensi E.faecalis pada gigi yang telah dilakukan perawatan saluran akar dan mengalami periodontitis apikalis kronis berkisar antara 29-64\%. Menurut penelitian Pinheiro et al (2003) didapatkan E.faecalis 20 dari 30 kasus infeksi endodontik sebagai penyebab infeksi persisten pada gigi yang telah mengalami perawatan saluran akar. E.faecalis menjadi penyebab terjadinya kelainan periapikal (Kaufman et al, 2005) dan memiliki prevalensi sebesar $89,6 \%$ pada kasus perawatan saluran akar ulang (retreatment), sementara pada kasus infeksi endodontik primer sebesar $67,5 \%{ }^{2}$

E.faecalis dapat persisten sebagai patogen pada tubuli dentin saluran akar karena dapat mengadakan ikatan pada dentin. Hal ini disebabkan karena E.faecaelis memiliki serine protease, gelatinase dan gelatin binding protein (Stuart et al, 2006). Menurut penelitian Sedgley et al, (2005), E.faecaelis dapat bertahan hidup pada saluran akar yang telah diobturasi selama 12 bulan. Menurut Kristich et al (2004), kemungkinan hal ini disebabkan oleh adanya kemampuan E.faecaelis untuk membentuk biofilm pada apikal yang tahan terhadap medikamen saluran akar yang diberikan. Specific cell surface protein (Esp) merupakan komponen penting pada pembentukan biofilm pada E.faecalis. Selain itu, adanya kapsul polisakarida serotipe $\mathrm{C}$ dan $\mathrm{D}$ merupakan faktor virulensi penting pada E.faecalis yang dapat mengakibatkan tidak terdeteksinya bakteri ini oleh sistem imun host. $^{3}$

Adanya iritasi komponen bakteri sebagai antigen dapat memicu respon imun pada daerah periapikal gigi. Salah satu faktor virulensi E.faecalis yang dapat memicu terjadinya reaksi imun adalah lipoteichoic acid (LTA). Menurut Lee et al (2009), LTA merupakan komponen virulensi utama dari Enterococcus faecalis yang dapat menyebabkan berbagai tingkatan inflamasi dan menimbulkan respon imun. LTA yang diisolasi dari
Enterococcus faecalis maupun pada bakteri gram positif lain dilaporkan menstimulasi leukosit untuk melepaskan mediator-mediator inflamatori, termasuk TNF- $\alpha$, IL-1 $\beta$, IL-6, IL-8 dan superoksida anion pada kultur sel monosit manusia dan PGE-2 pada kultur whole leukosit. Sedangkan pada kultur makrofag tikus didapatkan pelepasan enzim lisosomal (Seatre et al, 2001). Mediator-mediator ini juga dideteksi pada sampel periapikal yaitu TNF- $\alpha$, IL-1 $\beta$, IL-6, IL-8, PGE-2, enzim lisosomal dan superoksida anion. Selain itu, LTA juga menunjukkan afinitas perlekatan yang tinggi pada hidroksiapatit sehingga terjadi penetrasi yang dalam di tubuli dentin. ${ }^{4}$

Tumor Necrosis Factor (TNF) mewakili rumpun dari 2 polipeptida ( $\alpha$ dan $\beta)$. TNF- $\alpha$ dan TNF- $\beta$ mempunyai kemiripan aktivitas biologik yang merupakan simulator potensial pada resorpsi tulang. ${ }^{5}$ TNF menstimulasi osteoklastogenesis yang dilakukan secara invivo pada mencit yang mengalami defisiensi p100 protein prekursor dari NF$\kappa \mathrm{B}$ yang merupakan molekul sinyal pada RANKL untuk memediasi stimulasi osteoklastogenesis dan resorpsi tulang.

Growth factor meregulasi pertumbuhan dan diferensiasi dari sel nonhematopoietic. Transforming growth factors (TGFs) diproduksi oleh sel neoplastik yang mempunyai kemampuan untuk menginduksi sel non-neiplastik pada permukaan fibroblas pada kultur agar. Proses ini menunjukkan kesamaan dengan transformasi neoplastik pada sel normal menjadi sel malignant. Berdasarkan hubungannya dengan epidermal growth factors (EGF), maka TGFs dibagi menjadi TGF- $\alpha$ dan TGF- $\beta$. TGF- $\beta$ disintesis oleh berbagai sel normal dan platelet serta berpengaruh terhadap aktivasi dari makrofag, proliferasi fibroblas, sintesis dari serat jaringan ikat dan matriksnya, lokal angiogenesis, penyembuhan juga regulasi dari limfosit T. Maka dari itu, TGF- $\beta$ berperan sangat penting dalam 
melawan efek merugikan akibat respon host yaitu inflamasi. ${ }^{6}$

\section{MATERI DAN METODE}

Jenis penelitian yang digunakan adalah eksperimental laboratoris. Sampel penelitian menggunakan tikus jantan yang diperoleh dari Fakultas Kedokteran Hewan Universitas Airlangga, dewasa, jantan, umur 8 - 12 minggu, berat badan antara 120 - 150 gram, dengan alasan perubahan berat badan selama penelitian relatif kecil, gigi molar sudah tumbuh sempurna, kondisi fisik sehat. Besar sampel yang digunakan tiap-tiap kelompok adalah sebanyak 9 ekor tikus Wistar sehingga total sampel yang digunakan sebesar 27 ekor tikus Wistar. Tindakan awal yaitu tikus difixir pada papan retraksi rahang kemudian dilakukan tindakan perforasi atap pulpa molar atas dengan menggunakan mata bur no $1 / 4$. Tikus yang telah memenuhi persyaratan dilakukan anastesi via intra peritoneal dengan injeksi ketamin $80 \mathrm{mg} / \mathrm{kg}$ dan xylazine 10 $\mathrm{mg} / \mathrm{kg}$ berat badan.${ }^{9}$ Setelah itu penutupan kavitas menggunakan resin GIC pasca penetrasi E.faecalis ATCC212 sebanyak $10^{6} \mathrm{CFU}$.

Ada tiga kelompok perlakuan: Kelompok Perlakuan A. Sebagai kelompok kontrol negatif, gigi sehat tanpa dibur. Kelompok Perlakuan B dilakukan preparasi gigi hingga terjadi perforasi atap pulpa, pada hewan coba kelompok ini dilakukan injeksi BHIb steril. Kelompok Perlakuan $\mathrm{C}$ dilakukan preparasi gigi hingga terjadi perforasi atap pulpa, pada hewan coba kelompok ini dilakukan injeksi $10 \mu \mathrm{l}$ BHI-b berisi bakteri E.faecalis ATCC212 sebanyak $10^{6} \mathrm{CFU}$ dengan mikropipet. Lalu hewan coba dikorbankan pada hari ke 21. Tahap selanjutnya yaitu pemotongan jaringan dengan langkah-langkah sebagai berikut, euthanasia pada tikus dilakukan dengan dislokasi servikal, lalu tikus difiksasi pada meja kerja lalu dilakukan dekaputasi serta pemisahan cranium dengan mandibula. Masing-masing potongan rahang difiksasi pada $10 \%$ buffer formalin netral selama 24 jam dan didekalsifikasikan pada EDTA 4\% selama 30 hari kemudian dilakukan pembuatan sediaan blok parafin. Kemudian dilakukan pembuatan sediaan HPA (preparat) sehingga dapat dilihat adanya kerusakan tulang periapikal. Setelah dipastikan telah terjadi kerusakan maka selanjutnya dilakukan pengecatan imunohistokimia menggunakan antibodi anti TGF- $\alpha$ dan TGF- $\beta$ agar dapat dilihat dengan perbesaran $1000 x$ pada 20 lapang pandang dalam mikroskop cahaya untuk selanjutnya dilakukan perhitungan jumlah sel osteoklas yang mengekpresikan TGF- $\alpha$ dan TGF- $\beta$ di periapikal. Untuk kebutuhan inferensial, maka data yang diperoleh dari hasil penelitian ini dianalisa dengan uji statistik, yaitu: Uji normalitas untuk melihat apakah mempunyai distribusi yang normal dilakukan dengan uji KolmogorovSmirnov Test, Uji homogenitas untuk melihat homogenitas variant berdasarkan populasi berat badan umurnya dengan uji Levene Test, dan Uji t-test satu arah untuk melihat adanya pengaruh induksi E.faecalis terhadap perbedaan jumlah sel TGF- $\alpha$ dan TGF- $\beta$ pada setiap kelompok kontrol negatif (A), kelompok kontrol pelarut (B) dan kelompok perlakuan (C). Data dikatakan tidak ada beda bila $\mathrm{p}>$ 0,05 dan ada beda bila $\mathrm{p}<0,05$.

\section{HASIL DAN DISKUSI}

Setelah dilakukan pemeriksaan HPA dengan pewarnaan HE didapatkan bahwa pada jaringan periapikal gigi sudah terjadi keradangan yang ditandai dengan munculnya gambaran sel makrofag dan sel limfosit maka dilanjutkan dengan pemeriksaan imunohistokimia. 


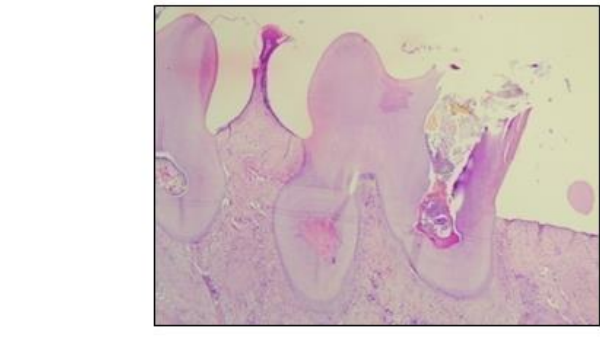

Gambar 1 Gigi. Molar Rahang Atas Kanan Tikus dengan Pengecatan HE Setelah Perforas Bur.

Setelah dilakukan pemeriksaan HPA dengan pewarnaan HE didapatkan bahwa pada jaringan periapikal gigi sudah terjadi keradangan yang ditandai dengan munculnya gambaran sel makrofag dan sel limfosit maka dilanjutkan dengan pemeriksaan imunohistokimia.

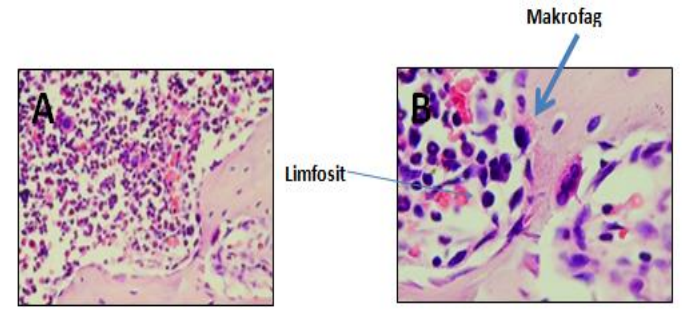

Gambar 2.a Jaringan Periapikal Gigi Molar Rahang Atas Kanan Tikus Setelah Perlakuan (Perbesaran 400x). 5.2.b Jaringan Periapikal Gigi Molar Rahang Atas Kanan Tikus Setelah Perlakuan (Perbesaran 1000x). Pada gambaran jaringan periapikal di atas didapatkan gambaran sel makrofag dan sel limfosit yang merupakan sel-sel keradangan

Pemeriksaan imunohistokimia untuk mengetahui jumlah sel yang mengekspresikan TNF- $\alpha$ dilakukan dengan cara pemulasan imunostaining menggunakan antibodi monoklonal anti mice TNF- $\alpha$. Tampak ekspresi TNF- $\alpha$ terdistribusi pada sitoplasma sel $\mathrm{T}$ jaringan periapikal
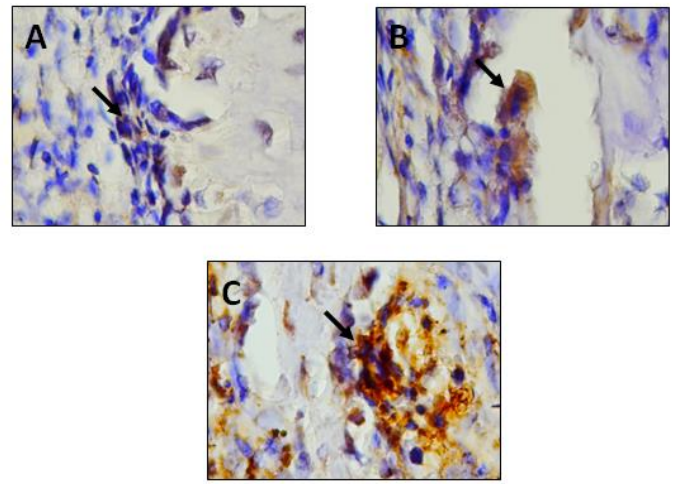

Gambar 5.3 Ekspresi TGF-ß (Warna Coklat) Keterangan: A, Kontrol negatif; B, Kontrol positif; C, Perlakuan (Perbesaran 1000x).

Pemeriksaan imunohistokimia untuk mengetahui jumlah sel yang mengekspresikan TGF- $\beta$ dilakukan dengan cara pemulasan imunostaining menggunakan antibodi monoklonal anti mice TGF- 3 . Tampak ekspresi TGF- 3 (warna coklat) terdistribusi pada sitoplasma sel $\mathrm{T}$ jaringan periapikal.
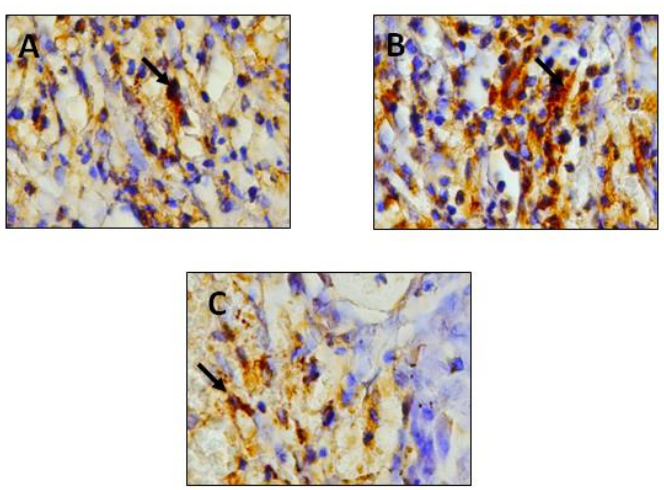

Gambar 5.4 Ekspresi TGF- $\beta \quad$ (Warna Coklat) Keterangan: A, Kontrol negatif; B, Kontrol positif; C, Perlakuan (Perbesaran 1000x).

Data hasil pengukuran dilakukan analisis data. Sebelum dilakukan analisis data, dilakukan uji normalitas dan uji homogenitas varians. Setelah dilakukan uji normalitas dan uji homogenitas varians, didapatkan bahwa data terdistribusi normal dan homogen (Tabel 2). 
Tabel 1 Rerata dan Standar Deviasi Ekspresi TNF$\alpha$

\begin{tabular}{|r|r|r|}
\hline Kelompok & Rerata & \pm SD \\
\hline $\begin{array}{c}\text { Kontrol } \\
\text { Negatif }\end{array}$ & 5,89 & 2,619 \\
\hline $\begin{array}{c}\text { Kontrol } \\
\text { Positif }\end{array}$ & 12,56 & 2,128 \\
\hline Perlakuan & 21,56 & 3,046 \\
\hline
\end{tabular}

Tabel 2 Hasil Uji Normalitas dan Homogenitas Ekspresi TNF- $\alpha$ dan Ekspresi TGF- $\beta$

\begin{tabular}{|c|c|c|}
\hline Ekspresi & $\begin{array}{c}\text { Signifikansi Uji } \\
\text { Normalitas }\end{array}$ & $\begin{array}{c}\text { Signifikansi Uji } \\
\text { Homogenitas }\end{array}$ \\
\hline TNF- $\alpha$ & 0,681 & 0,516 \\
\hline TGF- $\beta$ & 0,520 & 0,601 \\
\hline
\end{tabular}

Dari tabel di atas, dapat dilihat bahwa semua data ekspresi mempunyai $\mathrm{p}$ $\geq 0,05$ dan ini menunjukkan data tersebut berdistribusi normal dan homogen maka dilanjutkan dengan uji ANOVA $(p \leq 0,05)$.

Data nilai rerata dan standar deviasi (Tabel 2) sel yang mengekspresikan TNF- $\alpha$ pada jaringan periapikal menunjukkan bahwa pada kelompok kontrol negatif, kontrol positif dan perlakuan terjadi peningkatan jumlah sel yang mengekspresikan TNF- $\alpha$. Uji beda satu arah ANOVA pada seluruh kelompok menunjukkan perbedaan yang bermakna $(\mathrm{p}=0,000)$, untuk mengetahui perbedaan antar kelompok dilakukan uji Tukey HSD. Hasil uji antar kelompok menggunakan Tukey HSD melalui tabulasi silang (Tabel 3) didapatkan hasil terdapat perbedaan bermakna antara:

1. Kelompok kontrol negatif dengan kelompok kontrol positif

2. Kelompok kontrol negatif dengan kelompok perlakuan

3. Kelompok kontrol positif dengan kelompok perlakuan

Tabel 3 Uji Tukey Antar Kelompok Penelitian Ekspresi TNF- $\alpha$

\begin{tabular}{|l|l|l|l|}
\hline Kelompok & $\begin{array}{c}\text { Kontrol } \\
\text { Negatif }\end{array}$ & $\begin{array}{c}\text { Kontrol } \\
\text { Positif }\end{array}$ & Perlakuan \\
\hline
\end{tabular}

\begin{tabular}{|c|c|c|c|}
\hline $\begin{array}{c}\text { Kontrol } \\
\text { Negatif }\end{array}$ & - & $0,000^{*}$ & $0,000^{*}$ \\
\hline $\begin{array}{c}\text { Kontrol } \\
\text { Positif }\end{array}$ & $0,000^{*}$ & - & $0,000^{*}$ \\
\hline Perlakuan & $0,000^{*}$ & $0,000^{*}$ & - \\
\hline
\end{tabular}

Keterangan: Taraf Kemaknaan Bermakna $(\mathrm{p} \leq$ 0,05) Ditunjukkan Tanda *

Tabel 4 Rerata dan Simpang Baku Ekspresi TGF-ß

\begin{tabular}{|r|c|c|}
\hline Kelompok & Rerata & \pm SD \\
\hline $\begin{array}{c}\text { Kontrol } \\
\text { Negatif }\end{array}$ & 3,89 & 2,759 \\
\hline $\begin{array}{c}\text { Kontrol } \\
\text { Positif }\end{array}$ & 14,11 & 2,088 \\
\hline Perlakuan & 9,04 & 4,942 \\
\hline
\end{tabular}

Data nilai rerata dan standar deviasi (Tabel 4) yang mengekspresikan TGF- $\beta$ pada jaringan periapikal menunjukkan bahwa pada kelompok kontrol negatif, kontrol positif dan perlakuan terjadi peningkatan jumlah sel yang mengekspresikan TGF- $B$. Uji beda satu arah ANOVA pada seluruh kelompok menunjukkan perbedaan yang bermakna ( $\mathrm{p}=0,000)$, untuk mengetahui perbedaan antar kelompok dilakukan uji Tukey HSD. Hasil uji antar kelompok menggunakan Tukey HSD melalui tabulasi silang (Tabel 5) didapatkan hasil terdapat perbedaan bermakna antara:

1. Kelompok kontrol positif dengan kelompok perlakuan

2. Kelompok kontrol negatif dengan kelompok kontrol positif

3. Kelompok kontrol negatif dengan kelompok perlakuan

Tabel 5 Uji Tukey Antar Kelompok Penelitian Ekspresi TGF-ß

\begin{tabular}{|c|c|c|c|}
\hline Kelompok & $\begin{array}{c}\text { Kontrol } \\
\text { Negatif }\end{array}$ & $\begin{array}{c}\text { Kontrol } \\
\text { Positif }\end{array}$ & Perlakuan \\
\hline $\begin{array}{c}\text { Kontrol } \\
\text { Negatif }\end{array}$ & - & $0,000^{*}$ & $0,001^{*}$ \\
\hline $\begin{array}{c}\text { Kontrol } \\
\text { Positif }\end{array}$ & $0,000^{*}$ & - & $0,001^{*}$ \\
\hline
\end{tabular}


\begin{tabular}{|c|c|c|c|}
\hline Perlakuan & $0,001^{*}$ & $0,001^{*}$ & - \\
\hline
\end{tabular}

Keterangan: Taraf Kemaknaan Bermakna $(\mathrm{p} \leq$ 0,05) Ditunjukkan Tanda *

\section{Bakteri Enterococcus faecaelis} mempunyai beberapa faktor virulensi yang dapat menyebabkan infeksi endodontik, salah satunya adalah lipoteichoic acid (LTA) yang dapat menimbulkan reaksi imunologi. LTA melalui jalur Toll Like Receptor (TLR-2) pada tahap awal infeksi akan mengaktifkan Myeloid differentiation protein 88 (Myd 88) sehingga menginisasi sinyal aktivasi IL-1 receptor associated kinase (IRAK). IRAK ini kemudian akan melakukan pengambilan TNF-Receptor Associated Factors-6 (TRAF-6) yang berperan dalam fosforilasi inhibitor of kappa-B kinase (IKK) yang selanjutnya akan mengaktifkan $\mathrm{I}-\kappa \mathrm{B}$ kinase sehingga menghambat i $\mathrm{B}$

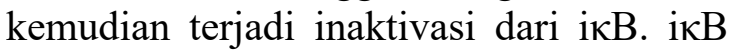
yang inaktif akan memicu aktivasi dari NF- $\kappa \beta$. Aktivasi dari NF- $\kappa \beta$ menghasilkan transkripsi yang akan menghasilkan TNF$\alpha$. Aktivasi dari NF- $\beta$ juga akan menghasilkan peningkatan TGF- $\beta$, adanya TGF- $\beta$ ini akan mensupresi inflamasi selama fase gingivitis maupun periodontitis.

Adanya peningkatan TNF- $\alpha$ akan memicu terjadinya peningkatan Receptor Activator of RANKL NF- $\kappa \beta$ Ligand (RANKL). Terjadinya peningkatan TNF- $\alpha$ dan RANKL akan menaikkan produksi Receptor Activator of RANKL NF- $\kappa \beta$ (RANK). Hal ini mengakibatkan terjadinya ikatan antara RANK dan RANKL yang kemudian menyebabkan pengambilan protein adapter $T N F$ Receptor Associated Factors-6 (TRAF-6). TRAF-6 akan menginduksi c Fos dan Activator protein 1 (AP-1) yang selanjutnya menginduksi Nuclear Factor of Activayed T cels cl (NFAT C1).

Ikatan RANK-RANKL yang menyebabkan pengambilan protein adapter TNF-Receptor Associated Factors-6 (TRAF-6) akan menyebabkan rangkaian transduksi sinyal yang menyebabkan peningkatan aktivasi NFATC1, peningkatan aktivasi dari NFATC1 yang berfungsi sebagai faktor transkripsi pembentukan osteoklas akan meningkatkan jumlah osteoklas yang matang, osteoklas matang ini selanjutnya akan membentuk osteoklas aktif sehingga akan merangsang terjadinya resorbsi tulang alveolar di periapikal.

Sedangkan tubuh yang mempunyai homeostasis akan mengkompensasi dengan munculnya growth factor yang distimulasi oleh IL-1ß yaitu TGF- $\beta$ yang paling berperan dalam menjaga keseimbangan bone modeling karena pembentukan osteoklas aktif. TGF- $\beta$ akan memicu adanya proliferasi fibroblas dengan melewati jalur Smad maupun nonSmad pathways.

Peningkatan jumlah sel yang mengekspresikan TNF- $\alpha$ dan TGF- $\beta$ tidak hanya terjadi pada kelompok perlakuan yang E.faecalis, tetapi juga pada kelompok kontrol positif yang tidak dilakukan induksi bakteri namun hanya dilakukan perforasi. Hal ini disebabkan karena aktifnya molekul tubuh yang dikeluarkan dari jaringan yang rusak, yaitu damageassociated molecular pattern (DAMP) salah satunya yaitu heat shock protein (HSP70). ${ }^{9}$ Pada keadaan normal HSP70 ada dalam konsentrasi yang kecil, dengan adanya rangsangan lingkungan (radiasi ultraviolet, panas, logam berat, dan asam amino), rangsangan patologis (virus,bakteri,infeksi parasit atau demam, keradangan, keganasan), atau rangsangan fisiologis (growth factor, diferensiasi sel, stimulasi hormon, atau perkembangan jaringan) mempengaruhi peningkatan sintesis HSP70. ${ }^{10}$ Pada kelompok kontrol positif, tindakan perforasi gigi merupakan salah satu rangsangan pembentukan HSP70.

Pada kelompok kontrol negatif, masih terdapat ekspresi TNF- $\alpha$ dan TGF- $\beta$ meskipun dalam jumlah yang relatif sedikit. Hal ini disebabkan karena TNF- $\alpha$ 
dan TGF- $\beta$ merupakan sitokin yang bersifat konstitutif. Berdasarkan mekanisme pengeluarannya, sitokin dibagi menjadi dua jenis yaitu sitokin konstitutif (constitutive cytokines) dan sitokin indusibel (inducible cytokines). Sitokin konstitutif merupakan sitokin yang tetap dikeluarkan dalam jumlah yang relatif sedikit dalam keadaan normal (fisiologis), tetapi akan meningkat jika terjadi jejas berupa kerusakan sel akibat bakteri,inflamasi dan lain sebagainya. Hal inilah yang mengakibatkan terdapat ekspresi TNF- $\alpha$ dan TGF- $\beta$. Sedangkan sitokin indusibel merupakan sitokin yang dalam keadaan normal tidak dikeluarkan sama sekali oleh sel, tetapi akan meningkat jika terjadi jejas pada sel tersebut. ${ }^{7}$

Pada penelitian ini membuktikan terjadi peningkatan jumlah sel pengekspresi TNF- $\alpha$ secara signifikan pada jaringan periapikal yang mengalami inflamasi akibat induksi bakteri E.faecalis dibandingkan dengan jaringan periapikal pada kelompok kontrol positif dan kontrol negatif. Hal ini membuktikan bahwa bakteri $E$. faecalis dapat menyebabkan inflamasi yang lebih parah pada jaringan periapikal dibanding dengan tindakan perforasi pulpa oleh bur pada kelompok kontrol positif.

Pada penelitian ini juga didapatkan hasil bahwa jumlah sel pengekspresi TGF$ß$ pada jaringan periapikal yang mengalami inflamasi akibat induksi bakteri E.faecalis lebih tinggi bila dibandingkan dengan jaringan periapikal pada kelompok kontrol negatif tetapi lebih rendah bila dibandingkan dengan kelompok kontrol positif mengingat TGF- $\beta$ merupakan regulator multifungsi dari pertumbuhan sel dan diferensiasi selama pembentukan dan perbaikan ${ }^{8}$ dan TGF- $\beta$ memiliki efek yang beragam (pleiotropik), diantaranya adalah sebagai inhibitor pertumbuhan bagi kebanyakan sel epitel dan bagi leukosit ${ }^{8}$ sehingga karena masih terjadi keradangan oleh bakteri E. faecalis pada jaringan periapikal gigi maka pengeluaran dari TGF-ß terhambat.

\section{KESIMPULAN}

Berdasarkan hasil penelitian yang telah dilakukan, maka dapat diambil kesimpulan sebagai berikut :

1. Jumlah sel pengekspresi TNF- $\alpha$ pada jaringan periapikal gigi tikus Wistar yang diberi perlakuan menggunakan bakteri E. Faecaelis lebih banyak dibanding dengan kelompok kontrol negatif dan kontrol positif

2. Jumlah sel pengekspresi TGF- $\beta$ pada jaringan periapikal gigi tikus Wistar yang diberi perlakuan menggunakan bakteri E. Faecaelis lebih banyak dibanding dengan kelompok kontrol negatif dan lebih sedikit dibanding dengan kelompok kontrol positif

\section{DAFTAR PUSTAKA}

1. Bergenholtz G, Preben HB, Reit C. 2010. Apical Periodontitis in Text Book of Endodontology, $2^{\text {nd }}$ ed. UK. Blackwell Publ Ltd. P 113-27.

2. Pinheiro ET, Gomes BP, Ferraz CC and Souza EL. 2003. Microorganism from Canals of Root Filled Teeth with Periapical Lessions. Int Endod J. 36 (1) : 1-11.

3. Rocas IN, Siquera JF Jr, Aboim MC, Rosado AS. 2004. Denaturing Gradient Gel Electrophoresis Analysis os Bacterial Communities Associated with Failed Endodontic Treatment. Oral Surg Oral Med Oral Pathol Oral Radiol Endod 98 : 74149.

4. Lorenzo J, Horowitz $M$ and Choi Y. 2008. Osteoimmunology : Interactions of The Bone and Immune System. Endocrine Rev. 29 (4) : 403-40. 
5. Coon D, Gulati A, Cowan C, He J. 2007. The Role of Cyclooxygenase2 (COX-2) in Inflammatory Bone Resorption. JOE. 35 (4) : 432-36.

6. Takayanagi H. 2007. The Role of NFAT in Osteoclast Formation. Ann NY Acad Sci. 116 : 227-37.

7. Asagiri M, Takayanagi H. 2009. The Molecular Ynderstanding of Osteoclast Differentiation Bone. 40 : 251-64.

7. Asagiri M, Takayanagi H. 2009. The Molecular Ynderstanding of Osteoclast Differentiation Bone. 40 : 251-64.
8. Aubin,J.E., Bonnelye E. 2000. Osteoprotegerin and Its Ligand a New Paradigm for Regulation of Osteogenesis and Bone Resorption. Osteoporos Int,11(11) 905-13.

9. Stashenko et al., 2007. Th1 Immune Response Promotes Severe Bone Resorption Caused by Porphyromonas gingivalis. American Journal of Pathology.170: Pp.203-13.

10. Abbas, A.K and Litchman, A.H. 2010. Cellular and Molecular Immunology. $4^{\text {th }}$ ed. Philadelphia: WB Saunders Company. P 235-69. 